John Carroll University

Carroll Collected

Sociology

2009

\title{
Selfhood in younger onset dementia: Transitions and testimonies.
}

Phyllis Braudy Harris

John Carroll University, pharris@jcu.edu

John Keady

Follow this and additional works at: http://collected.jcu.edu/soc-facpub

Part of the Medicine and Health Commons

\section{Recommended Citation}

Harris, Phyllis Braudy and Keady, John, "Selfhood in younger onset dementia: Transitions and testimonies." (2009). Sociology. 1. http://collected.jcu.edu/soc-facpub/1

This Article is brought to you for free and open access by Carroll Collected. It has been accepted for inclusion in Sociology by an authorized administrator of Carroll Collected. For more information, please contact connell@jcu.edu. 


\title{
Selfhood in younger onset dementia: Transitions and testimonies
}

\author{
Phyllis Braudy Harris, and John Keady \\ John Carroll University, Sociology, Cleveland, Ohio, United States; University of Manchester/Greater Manchester West \\ Mental Health NHS Foundation Trust, School of Nursing, Midwifery and Social Work, Manchester, UK
}

\begin{abstract}
Younger people with dementia and their carers are an overlooked population for research, policy and practice attention. In this study, data were collected from both the United States and the UK in order to explore the meaning and construction of selfhood and identity. The US data collection included in depth interviews with 23 people diagnosed with younger onset dementia, while the UK data collection comprised 15 face to face interviews with younger carers of younger people with dementia; all carers were/had been caring for a younger person with dementia diagnosed through the DSM IV R criteria. A grounded theory analysis of the data resulted in the emergence of five themes to explain the interview data, these were: (1) identity as a worker; (2) identity of abandoned individual; (3) sexual identity; (4) family identity; and (5) identity as an individual engaged in living. Additional research is necessary to further develop the attributes and application of these identity profiles.
\end{abstract}

Keywords: early onset dementia; Alzheimer's disease; lived experience of dementia; dementia carers

\section{Introduction}

Maintaining, creating and sustaining a sense of selfidentity and independence is a critical feature of adulthood, but for people diagnosed with dementia this can become a daunting and complex challenge. To accomplish this, people with dementia on one hand must acknowledge what is happening to their cognitive capacities with the distress that entails, whilst on the other hand they must be willing to struggle, often requiring the help of a family member, to maintain their sense of self. Contemporaneously, family members, who may be trying to assist the person with dementia to maintain a quality life, are grappling with the change that the diagnosis is having upon their own self-identity, as they transition from spouse or son/ daughter to a role of caregiver.

Early work on the selfhood of people with dementia concluded that a loss of self occurred as personality changed and cognitive and memory abilities diminished (Hammel et al., 1990; Sacks, 1985). Even one of the first popular guides written for families caring for someone with Alzheimer's disease was called The loss of self (Cohen \& Eisdorfer, 1986) and provided well-meaning guidance on ways to 'help the helpless' (p. 16). Over the last two decades though, we have come to realize that, although skills and social roles of the person with dementia become increasingly impaired, the core concept of who the person is, their held concept of self, remains (Harris \& Durkin, 2002; Harris \& Sterin, 1999; Henderson, 1998; Kitwood, 1997; Sabat, 1994, 2001, 2002). Research has also explored the impact that a diagnosis of dementia has on the identity of the carer. Findings reveal that the experience can make carers feel as if they are losing themselves as they put aspects of their own lives on hold to take care of loved ones (Aneshensal, Pearlin, Mullan, Zarit, \& Whitlatch, 1995; Harris \& Bichler, 1997).

One group though, in which this concept of selfhood is largely unexplored, are people with younger-onset dementia and their families (i.e. dementia occurring before the age of 65 years). Research has shown that younger people diagnosed with dementia and their families have unique and complex challenges to face. These issues include difficulties of getting a timely and proper diagnosis, issues of selfhood and self esteem, changing relationships within entire family structure, awareness of changes in self, workforce and retirement/financial issues, intense feelings of social isolation and being marginalized, off-time dependency, and boredom and lack of meaningful occupation (Cox \& Keady, 1999; Harris, 2004; Harris \& Keady, 2004; Williams, Keady \& Nolan, 1995). Other than through autobiographical accounts (see for example: FrielMcGowan, 1993; Rose, 2003; Taylor, 2007), the impact of dementia on this group's sense of self and self-identity has not been reported in any depth. Mutually affected areas of identity for both the younger person with dementia and family carer are explored in this study, alongside an awareness of this cohort as they journey through this transition. The two major research questions that guide this study are: (1) What happens to the selfhood of younger people diagnosed with dementia and their carer?; and (2) What lessons can be learned from their experiences that would be helpful to healthcare professionals, researchers, families, and persons with dementia? 


\section{Study design}

A grounded theory approach was chosen to provide an in-depth understanding of the subjective experience of younger people with dementia and their carers, primarily drawing on the work of Glaser and Strauss (1967) and Glaser (1978). As a qualitative phenomenological methodology, grounded theory is particularly useful when there is limited knowledge about a phenomenon. This means that an inductive approach is used that begins with individual experiences and findings are grounded in this specific context (Glaser \& Strauss, 1967). Thus, in the context of the reported study, the words of the participants are used to explain the impact of dementia on their selfhood.

\section{Data collection}

Data were collected from both the United States and the UK. These were purposive samples collected at different times for multiple purposes. One study was focusing on carers and one on persons with the dementia. The US data collection included in-depth interviews with 23 people diagnosed with youngeronset dementia and information was gathered through the following methods: focus groups, face-to-face interviews and on-line interviews. Participants were recruited from the Cleveland Area Alzheimer's Association and the Dementia Advocacy Support Group International, a group of people with an early diagnosis of dementia who have come together on their own to form an international self-help organization to advocate for their needs. In the sample the most common diagnoses were Alzheimer's disease and fronto-temporal dementia, and one person was diagnosed with Huntington's disease. Ten of the 23 people were male; the mean age at the time of the study was 56 with a range from 43 to 68 years, and the mean age at diagnosis was 53 years old with a range from 42 to 63 . The occupations were varied, from housewives and factory workers to professors and scientists. Eighteen people lived with a significant other and six had children under the age of 18 in the household. Seven people reported a family history of dementia, $11 \mathrm{knew}$ of no family history of the disease and the rest were unsure. All people interviewed were Caucasian and in the early stages of dementia with mild cognitive impairment (see Table 1).

In the UK, data collection comprised 15 faceto-face interviews with younger carers of younger people with dementia - these interviews were undertaken in north Wales and all carers were/had been caring for a younger person with dementia diagnosed through the $D S M-I V-R$ criteria (American Psychiatric Association, 1994). This sample included six co-habitant spouses (age range 40-64 years; caring history $1-6$ years, mean $=4.2$ years) and three adult children (age range 21-39 years; caring history 6 months to 7 years). Of the three adult child carers, one cared for their parent at a distance, one had moved in with their parent to provide more full-time support and one had placed their parent in a nursing home. Six

Table 1. Characteristics of US participants $\left(\begin{array}{ll}N & 23\end{array}\right)$ : Younger people with dementia.

\begin{tabular}{|c|c|c|c|c|c|c|c|c|}
\hline $\begin{array}{l}\text { Code } \\
\text { YPWD }\end{array}$ & Sex & Age & Diagnosis & $\begin{array}{l}\text { Age at } \\
\text { diagnosis }\end{array}$ & $\begin{array}{l}\text { Living } \\
\text { arrangements }\end{array}$ & $\begin{array}{l}\text { Family } \\
\text { history }\end{array}$ & $\begin{array}{l}\text { Occupation/ } \\
\text { previous work }\end{array}$ & $\begin{array}{l}\text { Data } \\
\text { collection }\end{array}$ \\
\hline 1 & $\mathrm{~F}$ & 63 & $\mathrm{AD}$ & 60 & Spouse & Yes & Teacher & On line \\
\hline 2 & $\mathrm{~F}$ & 63 & $\begin{array}{c}\text { Degenerative } \\
\text { dementia }\end{array}$ & 58 & Spouse & No & Child care provider & On line \\
\hline 3 & M & 57 & AD & 52 & Spouse & Yes & Social worker & Focus/interview \\
\hline 4 & M & 62 & $\mathrm{AD}$ & 58 & Alone & No & Professor & On line \\
\hline 5 & M & 68 & $\mathrm{AD}$ & 59 & Spouse & No & Salesperson & Focus/interview \\
\hline 6 & $\mathrm{~F}$ & 62 & $\mathrm{AD}$ & 58 & Friend & Yes & Teacher & Focus/interview \\
\hline 7 & $\mathrm{~F}$ & 53 & $\mathrm{AD}$ & 51 & Spouse & No & Factory worker & Focus/interview \\
\hline 8 & M & 63 & $\mathrm{AD}$ & 61 & Spouse & $?$ & Engineer & On line \\
\hline 9 & M & 55 & $\mathrm{AD}$ & 54 & Spouse & Yes & Salesperson & On line \\
\hline 10 & $\mathrm{~F}$ & 61 & AD & 59 & Spouse & No & Factory worker & Interview \\
\hline 11 & $\mathrm{~F}$ & 59 & $\mathrm{AD}$ & 55 & Spouse & $?$ & Housewife & Interview \\
\hline 12 & $\mathrm{~F}$ & 54 & $\mathrm{AD}$ & 53 & Alone & Yes & Book keeper & Interview \\
\hline 13 & $\mathrm{~F}$ & 51 & FTD & 46 & Spouse & Yes & Business owner & On line \\
\hline 14 & $\mathrm{~F}$ & 47 & FTD & 44 & $\mathrm{~W} /$ parents & $?$ & Business executive & On line \\
\hline 15 & $\mathrm{~F}$ & 53 & $\begin{array}{l}\text { MCI, benign } \\
\text { tumor }\end{array}$ & 49 & Significant other & No & Physician assistant & On line \\
\hline 16 & M & 66 & FTD & 63 & Spouse & Yes & Engineer & On line \\
\hline 17 & $\mathrm{~F}$ & 46 & AD & 43 & Spouse/children & No & Professor & On line \\
\hline 18 & M & 45 & HD & 41 & Spouse/children & $?$ & Businessman & On line \\
\hline 19 & M & 52 & FTD & 49 & Spouse/child & $?$ & & On line \\
\hline 20 & M & 61 & $\mathrm{AD}$ & 57 & Spouse/child/mother & No & Scientist & Focus/interview \\
\hline 21 & $\mathrm{~F}$ & 60 & $\mathrm{AD}$ & 56 & Spouse & No & Housewife & Interview \\
\hline 22 & $\mathrm{~F}$ & 43 & FTD & 42 & Spouse/child & No & Housewife & Interview \\
\hline 23 & M & 49 & FTD & 47 & Spouse/children & No & & On line \\
\hline
\end{tabular}


additional younger spouse carers were also recruited into the study. Of these six, each had previously cared for a younger person with dementia but no longer did so owing either to the death of that person $(N=3)$ or their admission into a continuing care facility $(N=3$; see Table 2). These additional carers were recruited to provide context and reflection on the caregiving journey and to consider points of transition and decision-making when the younger person with dementia was no longer living in the same home as other members of the family. All US data collection was undertaken by P.B.H., whilst the UK data collection was undertaken by J.K. Ethical approval to conduct the studies was provided by the appropriate research university and/or governance bodies in both the United States and the UK.

\section{Data analysis}

Using the analytical strategy suggested by Glaser and Strauss (1967), the transcripts and downloaded on-line interviews were read to develop substantive codes for each narrative. This involved a four-step process. First, each transcript and on-line interview was read in its entirety. Then, they were read a second time to develop codes that were grouped into themes, which emerged from the narratives and the interview guide. In order to be considered a major theme the code had to have appeared in over $50 \%$ of the narratives and more than once in each of those narratives. Third, a master list of themes from each interview was developed to allow for easy cross-interview examination. Finally, quotes that summarized the essence of each person's subjective experience were recorded on the master list.

There are many limitations to a qualitative study. The sample is small and the combined total of 38 participants certainly does not comprise a representative sample of people with younger-onset dementia and their family carers. Such limited sample sizes constrain the generalizability of the findings. This study also uses a cross-sectional method of data collection to examine a dynamic process, the impact of living with younger-onset dementia. However, qualitative research makes no claim to be representative of the population it is examining. The purpose of this methodology is to present a more in-depth, diverse and complex picture of a phenomenon than has been previously reported, and to identify possible variables that need to be tested and confirmed in larger representative studies. In addition, from the narratives comes a better understanding of the issues and complexities younger people with dementia and their carers face as they grapple with the need to maintain a sense of coherence and identity in their day-to-day life.

\section{Findings}

The analytical framework from which these narratives were examined was organized around the changing sense of self the person and carer experienced, as well as constants that remained. Permeating throughout these narratives are the disquieting and revealing insights of the person with dementia and their carer about what is occurring in their lives. Five themes that emerged from the narratives were: (1) identity as a worker; (2) identity of abandoned individual; (3) sexual identity; (4) family identity; and (5) identity as an individual engaged in living.

\section{Theme 1: Identity as a worker}

Given the age of participants in the study, it was perhaps unsurprising that discussion about the world of work provided a unified discourse across the data set. Indeed, in the course of all our daily lives, upon meeting someone for the first time, one of the first questions one usually asks is: 'What kind of work do you do?' One's occupation is often tied up with one's self-identity and sense of worth and societal status. However, with a diagnosis of dementia, it is usually this identity that is fractured first, especially in younger-onset dementia, for it is often in the workplace where the symptoms are first noticed:

\section{Person's perspective}

I lost everything that defined me as a productive and meaningful man when I had to stop working because of my symptoms. Eight months prior I had to quit driving because of running red lights and beginning to be in fender benders because of cognitive problems and lack of visuo spatial co ordination. This took the one 'thing' that gave me my most freedom. The whole role in life shifted from being the main breadwinner to now being Mr. Mom. (YPWD 18)

\section{Carer's perspective}

My day? It's all I can do to stay awake by the end of it. All I do is wash, clean and feed her and make sure she has some clean clothes to put on and the house is OK. If I'm lucky, someone will call to see me. But it's not often. I had a good job, you know, good money but I'm on scraps now. I often think what I will do when this is all over. I'll be too old to go back to work and nobody will really care what I have done. (Carer 4)

For the carer, his identity has changed from a worker in a recognized occupation that is monetarily rewarded to that of a caregiver, a position of low status that has little recognition or reward.

\section{Theme 2: Identity of abandoned individual}

For younger people with dementia and their carer it was rare to find any experiences where the impact of dementia had not significantly reduced the circle of social networks that previously sustained the person's and carer's lifestyle. From the data, these three examples best illustrate this experience. 
Table 2. Characteristics of UK participants $\left(\begin{array}{ll}N & 15\end{array}\right)$ : Carers of younger people with dementia.

\begin{tabular}{|c|c|c|c|c|c|c|c|c|}
\hline $\begin{array}{l}\text { Code } \\
\text { Carer }\end{array}$ & $\begin{array}{l}\text { Sex of } \\
\text { carer }\end{array}$ & $\begin{array}{l}\text { Age of } \\
\text { carer }\end{array}$ & $\begin{array}{l}\text { Diagnosis of } \\
\text { person } \\
\text { cared for }\end{array}$ & $\begin{array}{l}\text { Length of } \\
\text { caregiving } \\
\text { history } \\
\text { (from time } \\
\text { of diagnosis) } \\
\text { in year(s) }\end{array}$ & $\begin{array}{l}\text { Relationship } \\
\text { and living } \\
\text { arrangements }\end{array}$ & $\begin{array}{l}\text { Family } \\
\text { history }\end{array}$ & $\begin{array}{l}\text { Occupation/ } \\
\text { previous } \\
\text { work of carer }\end{array}$ & Data collection \\
\hline 1 & $\mathrm{~F}$ & 40 & $\mathrm{AD}$ & 1 & Spouse/co habiting & No & Homemaker & $\begin{array}{l}\text { Face to face } \\
\text { interview }\end{array}$ \\
\hline 2 & $\mathrm{~F}$ & 55 & $\mathrm{AD}$ & 5 & $\begin{array}{l}\text { Spouse/co habiting/ } \\
\text { two children at home }\end{array}$ & No & Teacher & $\begin{array}{l}\text { Face to face } \\
\text { interview }\end{array}$ \\
\hline 3 & M & 56 & $\begin{array}{l}\text { Vascular } \\
\text { dementia }\end{array}$ & 3 & Spouse/co habiting & No & Factory worker & $\begin{array}{l}\text { Face to face } \\
\text { interview }\end{array}$ \\
\hline 4 & M & 54 & FTD & 5 & Spouse/co habiting & No & Council worker & $\begin{array}{l}\text { Face to face } \\
\text { interview }\end{array}$ \\
\hline 5 & $\mathrm{~F}$ & 56 & $\mathrm{AD}$ & 4 & Spouse/co habiting & Yes & Businesswoman & $\begin{array}{l}\text { Face to face } \\
\text { interview }\end{array}$ \\
\hline 6 & M & 60 & $\mathrm{AD}$ & 6 & Spouse/co habiting & No & Car salesman & $\begin{array}{l}\text { Face to face } \\
\text { interview }\end{array}$ \\
\hline 7 & $\mathrm{~F}$ & 21 & FTD & 6 months & $\begin{array}{l}\text { Daughter/care at } \\
\text { a distance }\end{array}$ & No & Student & $\begin{array}{l}\text { Face to face } \\
\text { interview }\end{array}$ \\
\hline 8 & M & 32 & $\mathrm{AD}$ & 3 years & Son/living at home & Yes & Insurance salesman & $\begin{array}{l}\text { Face to face } \\
\text { interview }\end{array}$ \\
\hline 9 & $\mathrm{~F}$ & 39 & $\mathrm{AD}$ & 7 & $\begin{array}{l}\text { Daughter/alone/pwd } \\
\text { in care home }\end{array}$ & No & Hotel worker & $\begin{array}{l}\text { Face to face } \\
\text { interview }\end{array}$ \\
\hline 10 & M & 58 & $\begin{array}{l}\text { Vascular } \\
\text { dementia }\end{array}$ & 8 & $\begin{array}{l}\text { Spouse/alone/pwd } \\
\text { deceased }\end{array}$ & No & Lorry driver & $\begin{array}{l}\text { Face to face } \\
\text { interview }\end{array}$ \\
\hline 11 & M & 62 & $\mathrm{AD}$ & 10 & Spouse/alone/pwd deceased & Yes & Factory manager & $\begin{array}{l}\text { Face to face } \\
\text { interview }\end{array}$ \\
\hline 12 & $\mathrm{~F}$ & 59 & $\mathrm{AD}$ & 7 & Spouse/alone/pwd deceased & No & Teacher & $\begin{array}{l}\text { Face to face } \\
\text { interview }\end{array}$ \\
\hline 13 & $\mathrm{~F}$ & 58 & $\mathrm{AD}$ & 4 & $\begin{array}{l}\text { Spouse/alone/pwd } \\
\text { in care home }\end{array}$ & No & Businessman & $\begin{array}{l}\text { Face to face } \\
\text { interview }\end{array}$ \\
\hline 14 & $\mathrm{~F}$ & 64 & AD & 3 & $\begin{array}{l}\text { Spouse/alone/pwd } \\
\text { in care home }\end{array}$ & No & Voluntary worker & $\begin{array}{l}\text { Face to face } \\
\text { interview }\end{array}$ \\
\hline 15 & $\mathrm{~F}$ & 61 & $\mathrm{AD}$ & 6 & $\begin{array}{l}\text { Spouse/alone/pwd } \\
\text { in care home }\end{array}$ & No & Shop owner & $\begin{array}{l}\text { Face to face } \\
\text { interview }\end{array}$ \\
\hline
\end{tabular}

\section{Person's perspective}

I am a very social person. People counted on me and I felt good about it. I love to be with people. It's really hard because all my friends work. I don't have anyone 'to play with.' Now my friend is my TV. (YPWD 10) They [her friends] have all seemed to slowly disappear.

When I was first diagnosed I told them about me having Alzheimer's. They all said, 'Oh, what can I do?' I just asked them to remain being my friend; I don't know why they left. It hurts so badly. (YPWD 7) I no longer have friends; they found it too depressing in someone so young. They were unable to watch the changes. (YPWD 22)

\section{Carer's perspective}

I am just alone so much of the time. (Carer 1)

Social isolation as a consequence of living with the impact of a long-term condition is not a new phenomenon, and it has previously been reported as one of the most stressful events in family caregiving, both in the generic literature (Twigg \& Atkin, 1994) as well as in the dementia care literature more specifically (Aneshensal et al., 1995; Graff et al., 2006;
Harris, 1993). However, for younger people with dementia, the impact of this isolation can be devastating, particularly when the person himself or herself can be directly attributed to be the cause of this 'suffering'. As one carer stated: 'You would have to be a saint not to blame him [referring to her husband] for what he's reduced us to' (Carer-6).

\section{Theme 3: Sexual identity}

Sexual identity is an important part of self-image, although it is not something that people either in American or British cultures are at ease discussing. However, the importance of sexual identity to the centrality of a person's definition of self is well demonstrated by the quotes below:

\section{Person's perspective}

My life has changed in marriage. It is hard to feel attractive, or appealing when you have struggled all day just to make it through the day. It is hard to believe you are a person who would be wanted when you are nothing like the person your spouse married. (YPWD 11) 


\section{Carer's perspective}

I think I still love her, but it becomes more difficult every day. (Carer 6)

The physical side of our marriage is over; I'm only 56 for God's sake. What am I supposed to do now? (Carer 3)

There is limited study of sexual attractiveness in dementia, and fewer studies still that explore sexual intimacy involving both the people with dementia and their partners. What have most often been studied are problematic sexual behaviors of people with dementia or sexuality issues that arise in residential care (Black, Muralee \& Tampi, 2005; Buhr \& White, 2007; Harris \& Weir, 1998; Kuhn, 2002; Shaw, 2001; Ward, Vass, Aggarawl, Garfield, \& Cybyk, 2005). However, an early study by Litz, Zeiss and Davies (1990) drew attention to this aspect of human life and stated that 'many spouses of Alzheimer's patients are reluctant to report sexual difficulties and are even more reluctant to seek help' (p. 115). For younger people with dementia and their partners, this renegotiation of sexual roles, identity and intimacy within relationships requires additional study in order to open up the discourse and provide appropriate help and support.

\section{Theme 4: Family identity}

Our identity in families spans many roles from husband or wife, to father or mother, to son or daughter, to name just a few. Each role brings with it specific cultural and societal expectations about 'norms' of behavior. When unable to perform the family roles expected of us, role stress and conflict of varying intensity can occur. These three illustrations help clarify this:

\section{Person's perspective}

My memory is so bad that my youngest daughter would sometimes write her name all over my hand so that I wouldn't forget, and not pick her up [from school]. And then finally with a mother who could no longer drive their lives were changed dramatically, no longer could I take them to a friend's house, to Sunday school, or to a mall. While others saw paid help as a marvellous solution, they did not understand the emotional toll it took on my children to have others do what I once did, how it frightened them to have me losing abilities each month, each year. They were frightened that I was dying long before I had a diagnosis that I was. (YPWD 17)

I was a bright, energetic, leader in my field and community with three children and a spouse who depended upon me. I lost my career, my identity as a professional person, and my ability to support my family. Certainly a person who cannot think, has lost and is losing major roles cannot help but have that affect their sense of self. (YPWD 23)

\section{Carer's perspective}

Our children don't bring their friends to our house anymore...they find it too embarrassing with their Dad being the way he is. (Carer 2)
Seen in context of a family setting, it is a sobering reality that younger onset dementia has implications beyond the 'person-carer' dyad and delves into the realms of young children needing support (as the first quotation in this theme suggests) to understand the meaning and action of parents' behaviour (see Williams-Garwick, Detzner \& Boss, 1994). The family context of younger onset dementia is an agenda in need of further development.

\section{Theme 5: Identity as an individual engaged in living}

People hold core values that help define who they are, which remain constant as dementia progresses (Harris \& Sterin, 1999; Sabat 2001, 2002). To understand the core values of an individual is a step toward helping the person with dementia maintain their self-identity, and it also helps the carer better cope with the caregiving experience.

\section{Person's perspective}

I've told my children you needn't feel sorry for me. I still am who I want to be. What a shame it would be to live the rest of your life in regret. I'm not going to give up. I'm going to live until I die. (YPWD 10)

\section{Carer's perspective}

Everyday I ask myself how long this will carry on. He's been in the home for four years now and I want to get on with my life. (Carer 15)

\section{Carer's perspective}

The way I see Dad now means I want to live life as much as I can. You never know when it's your turn next. (Carer 7)

For some younger people with dementia in this study, being diagnosed with a devastating disease at an earlier age motivated them to face this adversity by consciously deciding to live life to the fullest (Harris \& Durkin, 2002) an experience that, at times, was also paralleled in the lives of family carers, especially teenage children.

\section{Discussion}

This study focused on exploring the psychosocial impact of younger-onset dementia on the selfhoods of the person and the family carer. It is evident from the shared narratives that all participants, in one way or another, had experienced a transition in their selfhood and identity from the time of diagnosis - or possibly beforehand when the first subtle changes to cognition or perception were noticed. This is perhaps not surprising as Sabat (2001) has commented that, 'There is a loss of control over various aspects of life as a result of living with Alzheimer's disease' 
(p. 154). Integral parts of self hood, components that comprise anyone's daily sense of self, are affected by this diagnosis from one's identity as a worker, family member, sexual and social being and as an individual engaged in living. And for the younger individuals with dementia and their family members, the disease occurs 'off time', not in their older years, as most often expected, but in the prime of their lives. This complicates the challenge in obtaining a diagnosis, adding to the stress already heaped upon the individuals and family unit. Moreover, whilst the syndrome of dementia in younger people is diverse (Harvey, Skelton-Robinson \& Rossor, 2003; Panegyres \& Frencham, 2007), an additional pressure involved in this cohort, particularly for younger-onset Alzheimer's disease (Newens et al., 1993), is the rapid progress through the stages of the condition (Cox \& Keady, 1999).

Even upon receipt of the diagnosis of dementia, for younger people, the diagnostic label does little to instill the possibility of a sense of hope and continuity in everyday roles. Indeed, it was the reverse that was experienced, evidenced by the narratives of loss and fear, which we heard and recorded above. Feelings of loss, fear and abandonment became the dominant forces in their lives, so much so that younger people with dementia (and their families) often ended up alone in the community with limited access to external help and support. To rectify this situation would take a major shift in social policy, public attitudes and health/social care funding. However, perhaps a more realistic starting point would be to raise public and employer awareness through a targeted health education and promotion campaign centred on recognizing the early signs of younger-onset dementia and the needs of families. Reducing stigma and promoting normalizing services for younger people with dementia would go a long way to positively supporting each of the five 'identity themes' outlined in this paper.

The values that underpin these services for people with dementia should be cognizant of the special needs of this group and the threats to identity that occur as a result. At present, in the UK and Ireland, specialist service provision for younger people with dementia and their families is woefully inadequate and services are, more often than not, folded into community and residential care provision for older people (Alzheimer's Society, 2006, 2007; Haase, 2005; National Audit Office, 2007), an occurrence that is mirrored in the United States (Alzheimer's Association, 2006) and other parts of the world (Alzheimer's Australia, 2007). Indeed, apart from a Health Advisory Service report in the mid 1990s (Health Advisory Service, 1997), in the UK policy for younger people with dementia is written into frameworks for older person's services (Department of Health, 2001). It is hoped that the Dementia Strategy in England will have an all-age focus (Banerjee \& Chan, 2008). In 2006 in the United
States, for the first time, the national office of the Alzheimer's Association publicly acknowledged the existence of this group of people by releasing a comprehensive report on the incidence, prevalence and special needs of people with early-onset dementia (Alzheimer's Association, 2006). Failure to address these needs in the United States and the UK will send a profoundly disturbing message to younger people with dementia and their families and undermine already fragile identities.

Dementia touches all members of the family, and in the context of younger people with dementia, perhaps more so and more acutely. Care is a complex and multi-faceted phenomenon and younger people with dementia wanted to retain positive identities and roles, particularly within their family structure. In many ways this is no different to the situation faced by people with dementia of whatever age (Koch $\&$ Crichton, 2007), but within our study the impact of dementia on younger and teenage children on family relationships caused additional hardship and upset that warranted further exploration. Accordingly, future studies should recognize the importance of prolonged engagement and longitudinal research designs which would add needed data necessary for an in-depth understanding of family adjustment and quality service provision (see Evidence Based Interventions for Dementia, EVIDEM, www.evidem. org.uk/; Harris \& Keady, 2006; Nolan, Ingleton \& Hayter, 2008).

Finally, to fully appreciate the temporal nature of self-identity, a sustained biographical approach to working with younger people with dementia and their family is also necessary. This approach should be located within the context of a community network and seen to act as a basis for life work and therapeutic engagement (Junaid \& Hegde, 2007; Rockwood, Wallack \& Tallis, 2003). Such work would help to empower younger people with dementia and their families and put their self-expressed needs centre stage in the dementia care arena.

\section{Acknowledgements}

To all the participants in the study who gave so freely of their time and hearts.

\section{References}

Alzheimer's Association (2006). Early onset dementia: A national challenge, a future crisis. Washington, DC: Alzheimer's Association.

Alzheimer's Society (2006). Ready or not: A survey of services available in the UK for younger people with dementia. London: Alzheimer's Society.

Alzheimer's Society (2007). Dementia UK: A report into the prevalence and cost of dementia. Prepared by the Personal Social Services Research Unit at the London School of Economics and the Institute of Psychiatry at 
King's College London, for the Alzheimer's Society. London: Alzheimer's Society. Retrieved 29 April, 2008 from http://www.alzheimers.org.uk/news_and_campaigns/ Campaigning/PDF/Dementia_UK_Full_Report.pdf

Alzheimer's Australia (2007). Exploring the needs of younger people with dementia in Australia: Report to Australian Government Department of Health and Ageing. NSW: Alzheimer's Australia.

American Psychiatric Association (1994). DSM IV: Diagnostic and statistical manual of mental disorders (4th ed.). Washington, DC: American Psychiatric Association.

Aneshensel, C.S., Pearlin, L.I., Mullan, J.T., Zarit, S.H., \& Whitlatch, C.J. (1995). Profiles in caregiving: the unex pected career. San Diego, CA: Academic Press.

Banerjee, S., \& Chan, J. (2008). Organization of old age psychiatric services. Psychiatry, 7(2), 4954.

Black, B., Muralee, S., \& Tampi, R.R. (2005). Inappropriate sexual behaviors in dementia. Journal of Geriatric Psychiatry and Neurology, 18(3), 155162.

Buhr, G.T., \& White, H.K. (2007). Difficult behaviors in long term care patients with dementia. Journal of American Medical Directors Association, 8(3, suppl. 2e), 101113.

Cohen, D., \& Eisdorfer, C. (1986). The loss of self. New York: Penguin Books.

Cox, S., \& Keady, J. (1999). Younger people with dementia: Planning, practice and development. London: Jessica Kingsley Publishers.

Department of Health (2001). National service framework for older people: Modern standards and service models. London: HMSO.

Friel McGowan, D. (1993). Living in the labyrinth: a personal journey through the maze of Alzheimer's. New York: Dell Publishing.

Glaser, B.G. (1978). Theoretical sensitivity. Mill Valley, CA: Sociology Press.

Glaser, B.G., \& Strauss, A.L. (1967). The discovery of grounded theory: Strategies for qualitative research. Chicago, IL: Aldine.

Graff, M.JL., Vernooij Dassen, M.J.M., Thijssen, M., Dekker, J., Willibrord, H.L., Hoefnagels, W.H.L., et al. (2006) Community based occupational therapy for patients with dementia and their care givers: randomised controlled trial. BMJ, doi:10.1136/bmj.39001.688843.BE (published 17 November 2006).

Haase, T. (2005). Early onset dementia: The needs of younger people with dementia in Ireland. Dun Laoghaire: The Alzheimer Society of Ireland.

Hammel, M., Gold, D.P., Andres, D., Reis, M., Dastoor, D., Grauer, H., et al. (1990). Predictors and consequences of aggressive behavior by community based dementia patients. The Gerontologist, 30, 206211.

Harris, L., \& Weir, M. (1998). Inappropriate sexual behavior in dementia: A review of the treatment literature. Sexuality and Disability, 16(3), 205217.

Harris, P.B. (1993). The misunderstood caregiver? A qualitative study of the male caregiver of Alzheimer's disease victims. The Gerontologist, 33(4), 551556.

Harris, P.B. (2004). The perspectives of younger people with dementia: Still an overlooked population. Social Work in Mental Health, 2(4), 1736.

Harris, P.B., \& Bichler, J. (1997). Men giving care: Reflections and husbands and sons. New York: Garland.

Harris, P.B., \& Durkin, C. (2002). Building reliance through coping and adapting. In P.B. Harris (Ed.), The person with Alzheimer's disease: Pathways to understanding the experience (pp. 165 184). Baltimore, MD: The Johns Hopkins University Press.

Harris, P.B., \& Keady, J. (2004). Living with early onset dementia: Exploring the experience and developing evi dence based guidelines for practice. Alzheimer's Care Quarterly, 5(2), 111122.

Harris, P.B., \& Keady, J. (2006). Editorial. Dementia: The International Journal of Social Research and Practice, 5(1), 59.

Harris, P.B., \& Sterin, G.J. (1999). Insider's perspective: Defining and preserving the self in dementia. Journal of Mental Health and Aging, 5(3), 241256.

Harvey, R.J., Skelton Robinson, M., \& Rossor, M.N. (2003). The prevalence and causes of dementia in people under the age of 65 years. Journal of Neurology, Neurosurgery and Psychiatry, 74, 12061209.

Health Advisory Service (1997). Heading for better care: Commissioning and providing mental health services for people who have acquired brain injury, early onset dementia or Huntington's disease. London: HMSO.

Henderson, C. (1998). Partial view: An Alzheimer's Journal. Dallas, TX: Southern Methodist University Press.

Junaid, O., \& Hegde, S. (2007). Supportive psychotherapy in dementia. Advances in Psychiatric Treatment, 13, 1723.

Kitwood, T. (1997). Dementia reconsidered: The person comes first. Buckinghamshire: Open University Press.

Koch, T., \& Crichton, J. (2007). Innovative approaches to living with dementia: an Australian case study. In M. Nolan, E. Hanson, G. Grant, \& J. Keady (Eds.), User participation in health and social care research: Voices, values and evaluation (pp. 89 103). Maidenhead: Open University Press/McGraw Hill.

Kuhn, D. (2002). Intimacy, sexuality, and residents with dementia. Alzheimer's Care Quarterly, 3(2), 165176.

Litz, B.T., Zeiss, A.M., \& Davies, H.D. (1990). Sexual concerns of male spouses of female Alzheimer's disease patients. Gerontologist, 30(1), 113116.

National Audirt Office (2007). Improving services and support for people with dementia. London: Stationery Office.

Newens, A.J., Forster, D.P., Kay, D.W., Kirkup, W., Bates, D., \& Edwardson, J. (1993). Clinically diagnosed presenile dementia of the Alzheimer type in the Northern Health Region: ascertainment, prevalence, incidence and survival. Psychological Medicine, 23(3), 631644.

Nolan, M., Ingleton, C., \& Hayter, M. (2008). The Research Excellence Framework (REF): A major impediment to free and informed debate? International Journal of Nursing Studies, 45(4), 487648.

Panegyres, P.K., \& Frencham, K. (2007). Course and causes of suspected dementia in young adults: a longitudinal study. American Journal of Alzheimer's Disease \& Other Dementias, 22(1), 56.

Rockwood, K., Wallack, M, \& Tallis, R. (2003). The treatment of Alzheimer's disease: success short of cure. The Lancet, 2, 630633.

Rose, L. (2003). Larry's Way: another look at Alzheimer's from the inside. New York: Universe.

Sabat, S.R. (1994). Excess disability and malignant social psychology: A case study of Alzheimer's disease. Journal of Community and Applied Social Psychology, 4, 157166.

Sabat, S.R. (2001). The experience of Alzheimer's disease: Life through a tangled veil. Oxford: Blackwell.

Sabat, S.R. (2002). Surviving manifestations of selfhood. Dementia: The International Journal of Social Research and Practice, 1(1), 2536. 
Sacks, O. (1985). The man who mistook his wife for a hat. New York: Harper Collins.

Shaw, J. (2001). When you're asked to speak about sex, intimacy, and Alzheimer's. Journal of Sex Education \& Therapy, 26(2), 140146.

Taylor, R. (2007). Alzheimer's from the inside out. Baltimore, MD: Health Professions Press.

Twigg, J., \& Atkin, K. (1994). Carers perceived: Policy and practice in informal care. Milton Keynes: Open University Press.
Ward, R., Vass, A.A., Aggarawl, N., Garfield, C., \& Cybyk, B. (2005). A kiss is still a kiss. Dementia: The International Journal of Social Research and Practice, 4(1), 4972.

Williams Garwick, A., Detzner, D., \& Boss, P. (1994). Family perceptions of living with Alzheimer's disease. Family Process, 33, 327340.

Williams, O., Keady, J., \& Nolan, M. (1995). Younger onset Alzheimer's disease: Learning from the experience of one spouse carer. Journal of Clinical Nursing, 4, 3136. 